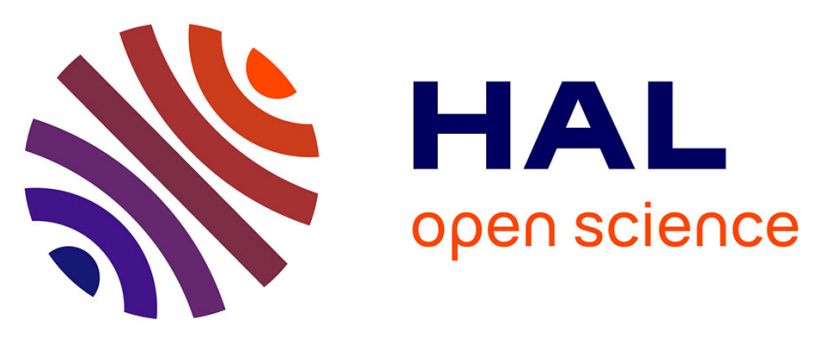

\title{
Roughness and texture of epitaxial LZO thin films grown on RABiTS Ni5W substrates
}

Jean-Louis Soubeyroux, Sarah Petit, Mélissa Mikolajczyk, Hervé Muguerra, Sébastien Pairis, Philippe Odier

\section{To cite this version:}

Jean-Louis Soubeyroux, Sarah Petit, Mélissa Mikolajczyk, Hervé Muguerra, Sébastien Pairis, et al.. Roughness and texture of epitaxial LZO thin films grown on RABiTS Ni5W substrates. IEEE Transactions on Applied Superconductivity, 2013, 23 (3), pp.7501004. 10.1109/TASC.2013.2241811 . hal00814809

\section{HAL Id: hal-00814809 \\ https://hal.science/hal-00814809}

Submitted on 17 Apr 2013

HAL is a multi-disciplinary open access archive for the deposit and dissemination of scientific research documents, whether they are published or not. The documents may come from teaching and research institutions in France or abroad, or from public or private research centers.
L'archive ouverte pluridisciplinaire $\mathbf{H A L}$, est destinée au dépôt et à la diffusion de documents scientifiques de niveau recherche, publiés ou non, émanant des établissements d'enseignement et de recherche français ou étrangers, des laboratoires publics ou privés. 


\title{
Roughness and texture of epitaxial LZO thin films grown on RABiTS Ni5W substrates
}

\author{
Jean-Louis Soubeyroux, Sarah Petit, Mélissa Mikolajczyk, Hervé Muguerra, Sébastien Pairis, Philippe Odier
}

\begin{abstract}
Low cost Coated Conductors (CC) are required in order to put together competitive superconducting cables. The buffer layer architecture is one of the key aspects of $\mathrm{CC}$ processing. Very interresting results have been obtained with complex architectures. It may not be necessary to have high Jc for cable applications, thus simpler architectures can be considered. We suggested that only one buffer could be sufficient. Because the YBCO deposition needs a perfect surface for epitaxy, we aim to eliminate the different defects appearing on this surface. To do so we suggest to identify the defects. We show the annealing results of the $\mathrm{NiW} / \mathrm{LZO}$ substrates with $\mathrm{La}_{2} \mathrm{Zr}_{2} \mathrm{O}_{7}$ (LZO) deposited by MOD at different annealing temperatures. The buffer layer microstructure is studied in detail and the texture is investigated as a function of the annealing temperature.
\end{abstract}

Index Terms - High-temperature superconductors; defects; Superconducting films, Coated conductors.

\section{INTRODUCTION}

$\mathrm{M}$ any examples of $\mathrm{La}_{2} \mathrm{Zr}_{2} \mathrm{O}_{7}$ oxide (LZO) buffer layer made by chemical solution deposition (CSD) have been synthesized on highly bi-axially textured $\mathrm{Ni}-5 \mathrm{at} \% \mathrm{~W}$ (Ni5W) substrates [1-6] obtained by the so called Rolling Assisted Biaxially Textured Substrate technique (RABiTS). LZO acts as a barrier against diffusion of the Ni toward YBCO [7, 8] and must limit the oxidation during the different steps of the synthesis process of the coated conductor $[9,10]$. This buffer layer is used as a template to grow epitaxially the superconducting layer made of $\mathrm{YBa}_{2} \mathrm{Cu}_{3} \mathrm{O}_{7}$ (YBCO) and for example deposited by MOCVD [11-12]. We focussed our studies on a simplified architecture composed of only the substrate, one LZO buffer layer and one YBCO superconducting layer. This choice was made with the perspective of making an economic process. Using the combination of CSD for the buffer and MOCVD for the YBCO, critical currents reaching or exceeding $1 \mathrm{MA} / \mathrm{cm}^{2}$ (self field at $77 \mathrm{~K}$ ) have been obtained on Ni5W RABiTS. So, the development of coated conductors requires attention to defects reducing the superconductivity. Their origin is not clear. It is then necessary to identify all possible sources of defects in the buffer that could induce misoriented grains in YBCO. Compared to more complexe architectures generally used

Manuscript received 06 october 2012. This work was supported in part by the CNRS, FEDER funds from EU under Grant 2009-017-000008.

J.L. Soubeyroux, S. Petit, M. Mikolajzyck, H. Muguerra, S. Pairis, Ph. Odier are with Institut Néel/CRETA-CNRS, 25 av. des Martyrs, BP166, 38042 Grenoble Cedex France (corresponding author J.L.Soubeyroux: 33(0)476889039; fax: 33(0)476881280; e-mail: mailto:jeanlouis.soubeyroux@grenoble.cnrs.fr ) (involving up to 5 or 6 intermediate layers), the detrimental contribution of defects in the buffer is more prominent. Rikel et al [13] showed the importance of the quality of the buffer layer in the case where one LZO buffer on Ni5W RABiTS substrate was covered with YBCO deposited by MOCVD.

LZO has a cubic structure with a $7.8 \%$ structural mismatch with Ni5W and is grown by epitaxy on Ni5W after a rotation of $45^{\circ}$ of its unit cell for better matching the substrate lattice [14]. Due to this property, many papers showed that LZO reproduced exactly the grain morphology of the substrate obtained by the RABiTS process [15]. The microstructure of LZO was made of small rounded crystallites $(20-50 \mathrm{~nm})$ with nanovoids $[7,14]$ originating from the released gases during the CSD process, but the crystallization process made these voids cubic [8]. The grain boundaries of the Ni substrate were transferred to the LZO microstructure by the epitaxial process giving rise to the typical grain morphology mentioned above. Twins that were present in the substrates were also reproduced in the LZO microstructure but with misorientations [16]. It is often said that twins must be suppressed as much as possible in metallic substrates for high superconducting performances of the YBCO layer. Other defects such as misorientations in the LZO surface layer have been observed [17-19], but no work has been dedicated to this kind of defects. The aim of this work was to investigate peculiarities of the microstructure of LZO buffer layers grown on Ni5W by CSD at different annealing temperatures. This paper focuses on misorientation defects observed by SEM-EBSD and X-ray techniques. It was discovered that these grains can change with annealing temperature while they keep a good texture.

\section{EXPERIMENTAL}

LZO films were deposited on Ni5W textured tapes (from Evico, Dresden) by CSD-MOD using propionate solutions prepared from acetylacetonate precursors [6] and dip-coated in the low evaporation mode (Landau mode). The film was then dried at $60^{\circ} \mathrm{C}$ for $2 \mathrm{~min}$. in air to form a solid polymer, subsequently pyrolyzed at $350^{\circ} \mathrm{C}$ for $60 \mathrm{~min}$. under primary vacuum or argon and finally crystallized at various temperatures for $30 \mathrm{~min}$. under flowing $\mathrm{Ar}-5 \% \mathrm{H}_{2}$ (heating rate $550^{\circ} \mathrm{C} / \mathrm{h}$ for both steps).

$\mathrm{X}$-ray data were measured with a four circles diffractometer (Seiffert, Germany) working at the $\mathrm{CuK} \alpha$ wavelength. The diffractometer is equipped with a Xenocs optic (Xenocs, France) allowing a small divergence $\left(0.06^{\circ}\right.$ horizontal $)$ of the $\mathrm{X}$-ray beam and a graphite monochromator before the analyzer.

SEM images were performed using a FEG-SEM from Zeiss (Zeiss ultra+, Germany) equipped with an EBSD unit using 
"HKL" monitoring software (Oxford Instruments). Atomic Force Microscopy (AFM) images were acquired with a Veeco D3100.

\section{RESULT AND DISCUSSION}

\section{A. The defects}

Fig. 1 shows a typical SEM top view with a 50000 times magnification. The LZO "normal" grains are columnar grains of 20 to $50 \mathrm{~nm}$ appearing in white. Some holes are also present and appear on this view as black spots. The other defects which are circled in white are larger (300-500 nm), seem to be flat and in the figure have a grey color.

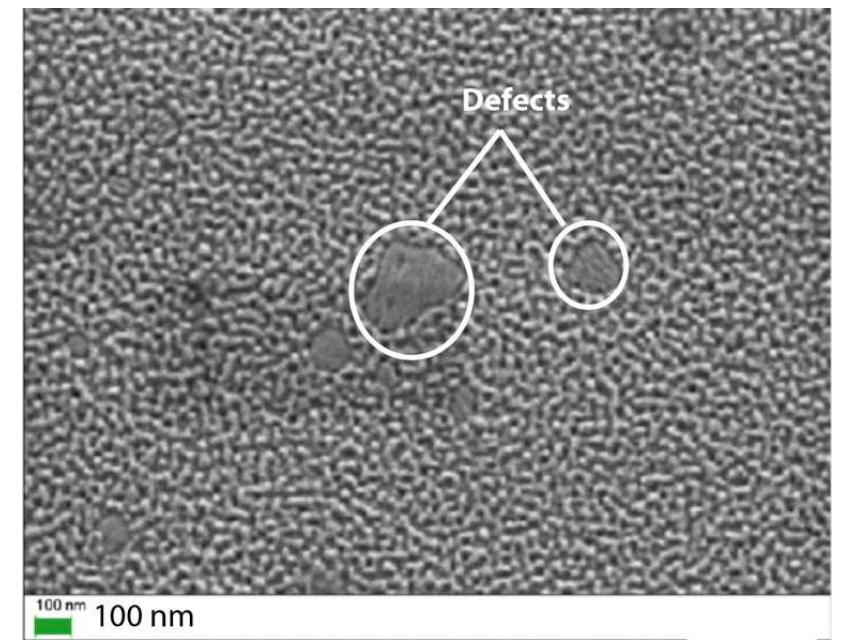

Fig. 1. SEM top view with a 50000 times magnification of the LZO layer annealed at $960^{\circ} \mathrm{C}$.

An AFM map of the same sample taken on a $1 \mathrm{x} 1 \mu \mathrm{m}^{2}$ square surface is shown in Fig. 2. The columnar LZO grains are shown in white and the defect is easily recognizable. A transverse profiling is given in the insert. The depth is $4 \mathrm{~nm}$ and the width $400 \mathrm{~nm}$.

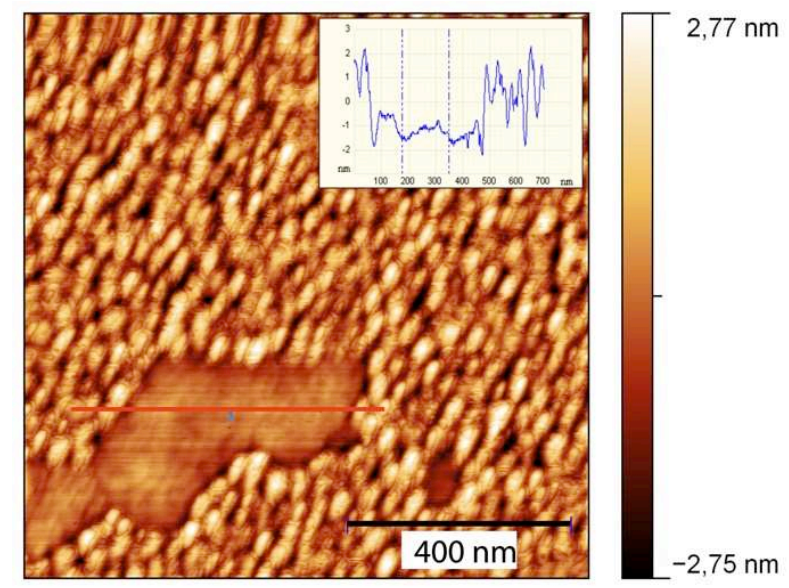

Fig. 2. AFM map of the LZO layer annealed at $960^{\circ} \mathrm{C}$.

This kind of defects can cover more than $5 \%$ of the surface as measured by image analysis on a SEM top surface view (the defects appear as darker grey than "normal" grains). They are not favorable as epitaxial centers for the next buffer layer as we have oberved by EBSD that inside a defect the orientation was very different from the $<001>$ one. Morover, a rugosity of the order of a nanometer is requiried together with a good lattice match. So these defects have to be avoided in order to grow YBCO on top of LZO.

\section{B. The effect of annealing temperature}

In previous studies, we demonstrated that a fast heating rate was necessary during the crystallization process [20] but we stopped our study of the annealing temperature at $960^{\circ} \mathrm{C}$, because we were mainly studying this effect on the porosity of the LZO layer. We did not pay a closer attention to the surface morphology.

Several experiments were performed at crystallization temperatures of 980,1020 and $1060^{\circ} \mathrm{C}$ for $30 \mathrm{~min}$. under flowing $\mathrm{Ar}: 5 \% \mathrm{H}_{2}$, all the other parameters were kept constant such as dip-coating extraction speed, drying temperature and using a first stage at $350^{\circ} \mathrm{C}$ under primary vaccuum. Fig. 3 shows a top surface view by SEM of a LZO layer annealed at $980^{\circ} \mathrm{C}$. The previously described defects can be seen as slightly darker grey. A calculation by image analysis using the Visilog ${ }^{\mathrm{TM}}$ software shown in the insert evidenced these areas in red, a $4 \%$ contribution to the total surface was obtained.

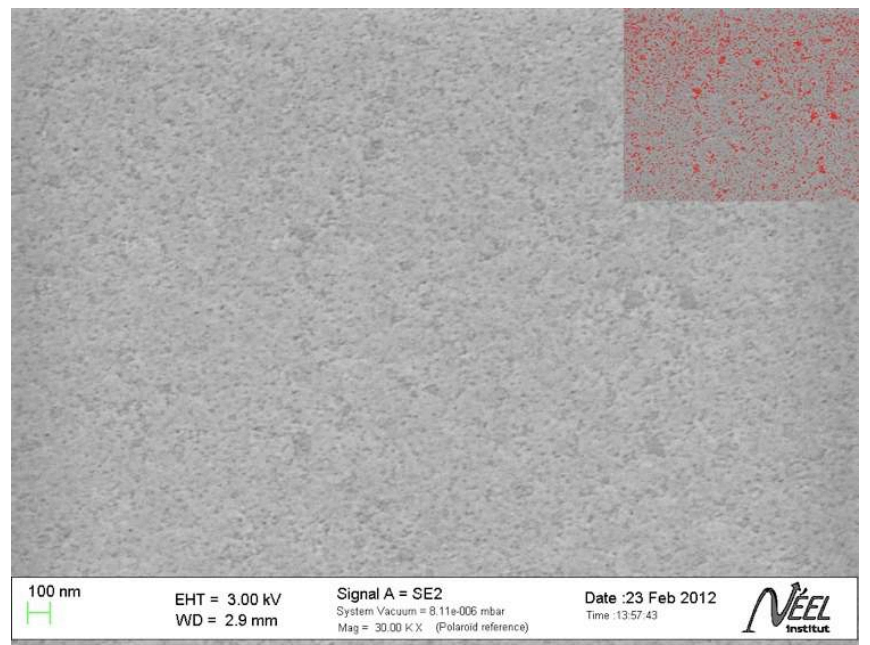

Fig. 3. SEM top surface view of a LZO layer annealed at $980^{\circ} \mathrm{C}$. In the insert, image analysis of the defects.

Fig. 4 shows the top surface view by SEM of a LZO layer annealed at $1020^{\circ} \mathrm{C}$. The defects are less numerous as a calculation of the surface occupied by defects is only $1 \%$.

Fig. 5 shows the top surface view by SEM of a LZO layer annealed at $1060^{\circ} \mathrm{C}$. The grains morphology is completely different from previous observations and the defects are not present as such.

More surface analysis have been done by EBSD. From Fig. 6 a to $8 \mathrm{a}$ the EBSD maps of the cube texture components $(<001>$ component is in red) of the LZO layer after annealing at the different temperatures are shown. For $980^{\circ} \mathrm{C}$ (Fig. 6a), $98.4 \%$ of the scan points have been indexed as LZO phase and only some regions appear in black, meaning no indexation from a single phase or presence of an amorphous grain. A maximum misorientation of $13^{\circ}$ was measured.

For $1020^{\circ} \mathrm{C}$ (Fig. 7a), $98.9 \%$ of the scan points have been indexed as LZO phase and no region appears in black. This means that the surface of the LZO layer is well adapted for a 
new epitaxial phase that will be deposited on top. A maximum misorientation of $15^{\circ}$ was measured.

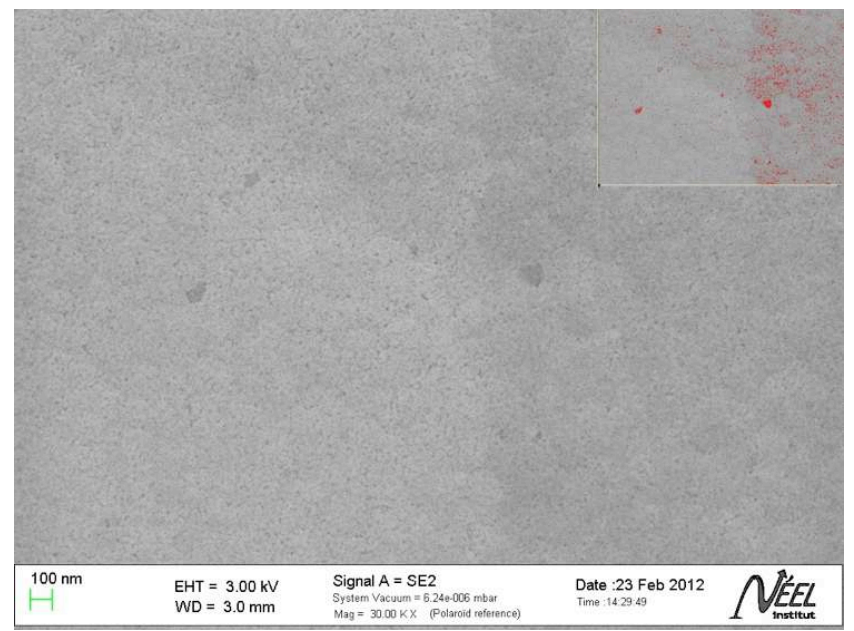

Fig.4. SEM top surface view of a LZO layer annealed at $1020^{\circ} \mathrm{C}$. In the insert, image analysis of the defects.

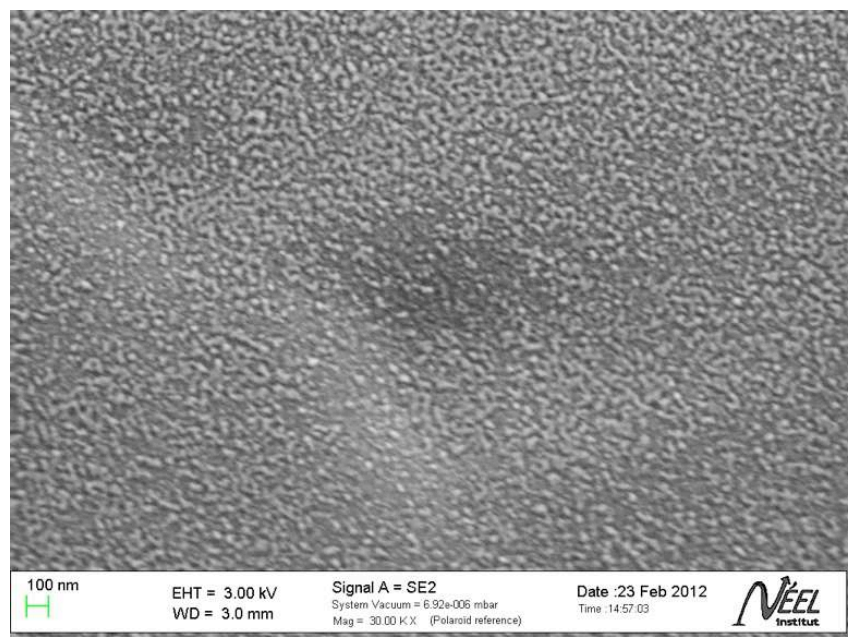

Fig. 5. SEM top surface view of a LZO layer annealed at $1060^{\circ} \mathrm{C}$.
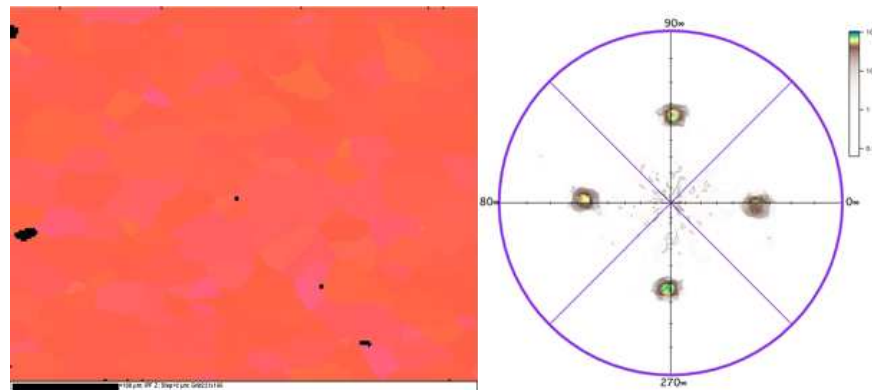

Fig. 6. a) SEM-EBSD mapping and b) X-ray (222) pole figure of a LZO layer annealed at $980^{\circ} \mathrm{C}$.

For $1060^{\circ} \mathrm{C}$ (Fig. 8a), $75.6 \%$ of the scan points have been indexed as LZO phase while many points appear in black. By a close examination of the Kikuchi patterns of these black points it appears that most of them present a multiple set of lines indicating several misorientations in the analyzed scan surface. A maximum misorientation of $16^{\circ}$ was measured.

Analysis of the orientations have also been made by X-ray diffraction. Pole figures (001) and (222) and scans in rolling direction (RD) and transverse direction (TD) have been made. Because of their penetrating power the $\mathrm{CuK} \alpha \mathrm{X}$-rays used analyze the entire layer thickness $(100 \mathrm{~nm})$. Fig. $6 \mathrm{~b}$ to $8 \mathrm{~b}$ show the (222) pole figures of the LZO layer annealed at various temperatures. Table I reports the measured FWHM.
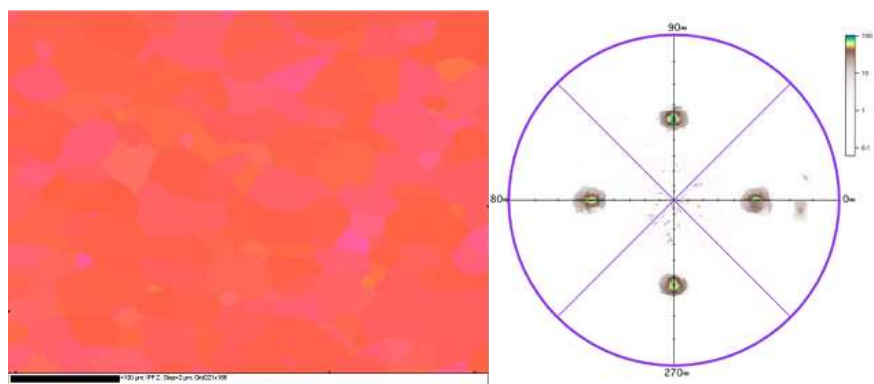

Fig. 7. a)SEM-EBSD mapping and b)X-ray (222) pole figure of a LZO layer annealed at $1020^{\circ} \mathrm{C}$.
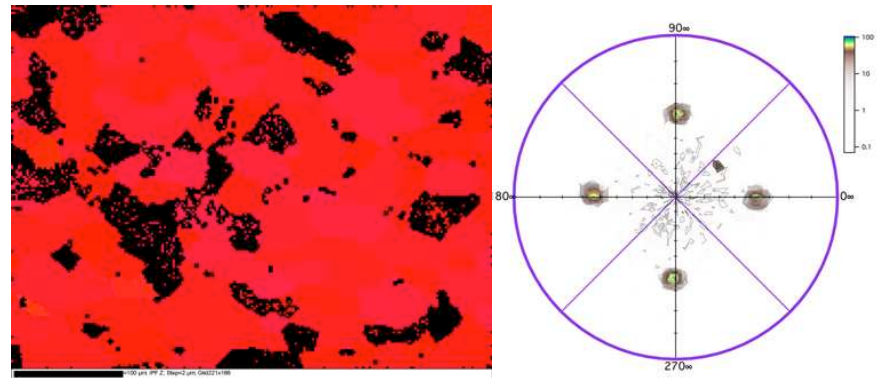

Fig. 8. a)SEM-EBSD mapping and b)X-ray (222) pole figure of a LZO layer annealed at $1060^{\circ} \mathrm{C}$.

For the three temperatures studied the results obtained by this analysis are quite similar as the pole figures show well defined spots. The quality of the texture is measured by the width of the rocking curves along different directions. The film quality depends upon the smallest width and the best roundness of the spots. As the highest temperature gives the roundest spots and the smallest FWHM values, we can state following these criteria that the texture quality is increasing with temperature. However, these criteria don't take into account the amorphous grains that don't diffract in the directions measured in pole figures. We can also observe on the (222) pole figure of the LZO layer and of the (111) pole figure of the Ni5W substrate that they present less twins than the starting substrate by annealing the LZO buffer at $1020^{\circ} \mathrm{C}$. These twins are present in these pole figures in the middle of the map.

TABLE I

TEXTURE PARAMETERS, PERCENTAGE OF KIKUCHI LINES INDEXED IN EBSD, AFM ROUGHNESS AT DIFFERENT ANNEALING TEMPERATURES

\begin{tabular}{cccccc}
\hline \hline $\begin{array}{c}\text { Annealing } \\
\text { temperature } \\
\left({ }^{\circ} \mathrm{C}\right)\end{array}$ & $\begin{array}{c}\text { LZO } \\
\text { 004 peak } \\
\text { RX } \\
\text { intensity }\end{array}$ & $\begin{array}{c}\text { FWHM of } \\
\text { rocking } \\
\text { curve along } \\
\mathrm{RD}\left({ }^{\circ}\right)\end{array}$ & $\begin{array}{c}\text { FWHM of } \\
\text { rocking } \\
\text { curve along } \\
\text { TD }\left({ }^{\circ}\right)\end{array}$ & $\begin{array}{c}\text { EBSD } \\
\% \text { indexed }\end{array}$ & $\begin{array}{c}\text { AFM } \\
\text { Ra } \\
(\mathrm{nm})\end{array}$ \\
\hline 980 & 127 & 6.47 & 5.93 & 98.4 & 2.35 \\
1020 & 134 & 6.63 & 5.85 & 98.9 & 0.95 \\
1060 & 98 & 6.44 & 5.82 & 75.6 & 2.10 \\
\hline \hline
\end{tabular}

We have also used the AFM technique in order to obtain another view of the LZO layer surface. Fig. 9 shows the map for the sample annealed at $1020^{\circ} \mathrm{C}$. The $\mathrm{LZO}$ grains are 
identical to those of the previous studies with a round top shape and a size of $20 \mathrm{~nm}$ [11]. The Ra roughness measured on the $25 \mu \mathrm{m}^{2}$ full surface is $0.95 \mathrm{~nm}$ and the Rms is $1.24 \mathrm{~nm}$, which correspond to lower values than those measured on different samples by Sathyamurthy $(5.4 \mathrm{~nm})$ [21] or Knoth $(3 \mathrm{~nm})$ [2]. More results corresponding to different temperatures are reported in Table I.

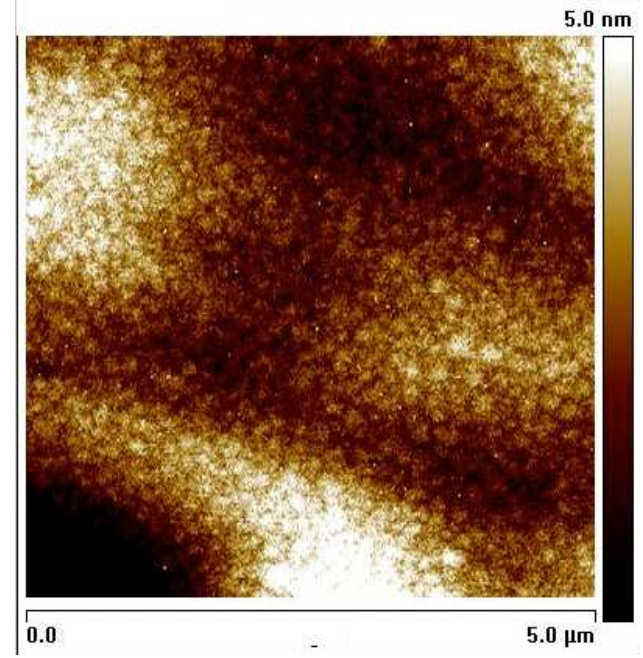

Fig. 9. AFM map performed on $\mathrm{LZO}$ annealed at $1020^{\circ} \mathrm{C}$.

\section{CONCLUSION}

We have been able to increase the surface quality of the LZO layer by annealing it at higher temperatures than those previously used and keeping the same profile temperature for the whole process. The best temperature used was $1020^{\circ} \mathrm{C}$. An unexpected fact when the annealing was performed at higher temperature was the twinning reduction. It can be supposed that a higher temperature may change the substrate texture and consequently the nucleation at the surface of the metallic substrate. Too high temperature such as $1060^{\circ} \mathrm{C}$ may change the substrate texture too much which may cause wrong orientations degrading the LZO epitaxy.

New YBCO layer deposition by MOCVD has been done by the PerCoTech company (http://percotech.com/en/home) [12] on a sample annealed at $1020^{\circ} \mathrm{C}$. The quality of this not very thick layer $(350 \mathrm{~nm})$ gave a transport current of the order of $1 \mathrm{MA} / \mathrm{cm}^{2}$. Further work is under way, in particular the effect of a second buffer layer on the current transport properties.

\section{ACKNOWLEDGMENT}

The authors thank Drs C.E. Bruzek and A. Allais from Nexans France and C. Jimenez from LMGP/Grenoble-INP for fruitful discussions.

\section{REFERENCES}

[1] S. Sathyamurthy, M. Paranthaman, T. Aytug, B.W. Kang, P.M. Martin, A. Goyal, D.M. Kroeger, D.K. Christen. " Chemical Solution Deposition of Lanthanum Zirconate Buffer Layers on Biaxially Textured Ni-1.7\% Fe-3\% W Alloy Substrates for Coated-conductor Fabrication" J. Mater. Res., vol.17, pp.1543-1549, 2002.

[2] K. Knoth, R. Hühne, S. Oswald, L. Schultz, B. Holzapfel. "Detailed investigations on $\mathrm{La}_{2} \mathrm{Zr}_{2} \mathrm{O}_{7}$ buffer layers for YBCO-coated conductors prepared by chemical solution deposition", Acta Mater., vol. 55, pp. 517-529, 2007.

[3] H. Chen, R. Kumar, B. A. Glowacki. "Chemical solution deposited lanthanum zirconium oxide thin films: Synthesis and chemistry" Materials Chemistry and Physics, vol. 122, pp. 305-310, 2010.
[4] Y. Cheng, H. Suo, M. Gao, M. Liu, L. Ma, M. Zhou, Y. Ji., " Characterization of MOD-derived $\mathrm{La}_{2} \mathrm{Zr}_{2} \mathrm{O}_{7}$ epi-layers on textured Ni5W substrates by electron backscattered diffraction" Acta Materialia, vol. 59, pp. 2823-2830, 2011.

[5] M. Paranthaman, S. Sathyamurthy, Xiaoping Li, E. D. Specht, S. H. Wee, C. Cantoni, A. Goyal, M.W. Rupich, " Modified Lanthanum Zirconium Oxide buffer layers for low-cost, high performance YBCO coated conductors", Physica C, vol. 470, pp. 352-356, 2010.

[6] V. Roche, C. Jimenez, P. Chaudouët, R. Benaboud, F. Weiss, E. Sarigiannidou, " Microstructural changes induced by the pyrolysis step on epitaxial $\mathrm{La} 2 \mathrm{Zr} 2 \mathrm{O} 7$ thin films grown by metalorganic decomposition", Thin Solid Films, vol. 520, pp. 2566-2574, 2012.

[7] L. Molina, K. Knoth, S. Engel, B. Holzapfel, O. Eibl. "Chemically deposited $\mathrm{La}_{2} \mathrm{Zr}_{2} \mathrm{O}_{7}$ buffer layers for YBCO-coated conductors: film growth and microstructure", Supercond.Sci.Technol., vol. 19, p. 1200, 2006.

[8] L. Molina, H. Y. Tan, E. Biermans, K. J. Batenburg, J. Verbeeck, S. Bals, G. Van Tendeloo, " Barrier efficiency of sponge-like $\mathrm{La}_{2} \mathrm{Zr}_{2} \mathrm{O}_{7}$ buffer layers for YBCO-coated conductors" Supercond. Sci. Technol. vol. 24, p. 065019, 2011.

[9] Y. Wang, L. Zhou, Y. F. Lu, C. S. Li, Z. M. Yu, L. H. Jin, J. S. Li., " Behavior of oxygen diffusion in buffer layers for coated conductors" J. Alloys and Compounds, vol. 509, pp. 8812-8824, 2011.

[10] S. Petit, M. Mikolajczyk, J. L. Soubeyroux, T. Waeckerlé, R. Batonnet, S. Pairis, P. Odier, " LZO, a Protective Barrier Against Oxidation of NiW Alloys", IEEE Trans. on Applied Supercond., vol. 21, pp. 29772980, 2011.

[11] T. Caroff, S. Morlens, A. Abrutis, M. Decroux, P. Chaudouet, L. Porcar, Z. Saltyte, C. Jimenez, P. Odier, F. Weiss, " $\mathrm{La}_{2} \mathrm{Zr}_{2} \mathrm{O}_{7}$ single buffer layer for YBCO RABiTS coated conductors", Supercond. Sci. Technol., vol. 21, p. 075007, 2008.

[12] O. Stadel, R. Y. Muydinov, G. Braüer, M. Rikel, J. Ehrenberg, J. Bock, G. Kotzyba, R. Nast, W. Goldacker, S. V. Samoylenkov, A. R. Kaul., " MOCVD and MOD of YBCO and Buffer Layers on Textured Metal Tapes", IEEE Trans.on Appl.Supercond., vol. 19, pp.3160-3163, 2009.

[13] M. Rikel, D. Isfort, M. Klein, J. Ehrenberg, J. Bock, E. D. Specht, M. Sun-Wagener, O. Weber, D. Sporn, S. Engel, O. de Haas, R. Semerad, M. Schubert, B. Holzapfel, "Simplified Procedure for Estimating Epitaxy of $\mathrm{La}_{2} \mathrm{Zr}_{2} \mathrm{O}_{7}$-Buffered NiW RABITS Using XRD", IEEE Trans. on Applied Supercond., vol. 19, pp. 3307-3310, 2009.

[14] L. Rapenne, C. Jimenez, T. Caroff, C. Million, S. Morlens, P. BayleGuillemeaud, F. Weiss., " High-resolution transmission electron microscopy observations of $\mathrm{La}_{2} \mathrm{Zr}_{2} \mathrm{O}_{7}$ thin layers on $\mathrm{LaAlO} 3$ obtained by chemical methods", J.Mater.Res., vol. 24, pp. 1480-1491, 2009.

[15] K. Knoth, R. Hühne, S. Oswald, L. Schultz, B. Holzapfel, " Highly textured $\mathrm{La}_{2} \mathrm{Zr}_{2} \mathrm{O}_{7}$ buffer layers for YBCO-coated conductors prepared by chemical solution deposition", Supercond. Sci. technol., vol. 18, pp. 334-339, 2005.

[16] S. Petit, S. Pairis, M. Mikolajczyk, L. Ortega, J-L. Soubeyroux, P. Odier, "Effect of twins in Ni substrates on the microstructure of LZO films for coated conductors", Thin Solid Films, accepted for publication.

[17] K. Knoth, R. Hühne, S. Oswald, L. Molina, O. Eibl, L. Schultz, B. Holzapfel, " Growth of thick chemical derived pyrochlore $\mathrm{La}_{2} \mathrm{Zr}_{2} \mathrm{O}_{7}$ buffer layers for $\mathrm{YBa}_{2} \mathrm{Cu}_{3} \mathrm{O}_{7-\mathrm{x}}$ coated conductors", Thin Sol. Film, vol. 516, pp. 2099-2108, 2008.

[18] L. Molina, S. Engel, K. Knoth, R. Hülne, B. Holzapfel, O. Eibl, " Grain growth and biaxial texture of chemically deposited $\mathrm{La}_{2} \mathrm{Zr}_{2} \mathrm{O}_{7}$ buffer layers for YBCO-coated conductors“, J. of Physics: Conf. Series, vol. 97, p. 012108,2008

[19] V. Narayanan, P. Lommens, K. De Buysser, I. Van Driessche, " Thick lanthanum zirconate buffer layers from water-based precursor solutions on Ni-5\%W substrates" J. of Sol. Sta. Chem., vol. 184, pp.2887-2896, 2011.

[20] C. Jimenez, T. Caroff, L. Rapenne, S. Morlens, E. Santos, P. Odier, F. Weiss, "Effect of the annealing process on the microstruture of $\mathrm{La}_{2} \mathrm{Zr}_{2} \mathrm{O}_{7}$ thin layers epitaxially grown on $\mathrm{LaAlO}_{3}$ by metalorganic decomposition" Journal of Crystal Growth, vol. 311, pp. 3204-3210, 2009.

[21] S. Sathyamurthy, M. Paranthaman, H.Y. Zhai, S. Kang, T. Aytug, C. Cantoni, K.J. Leonard, E.A. Payzant, H.M. Christen, A. Goyal, X. Li, U. Schoop, T. Kodenkandath and M.W. Rupich, " Chemical solution deposition of lanthanum zirconate barrier layers applied to low-cost coated-conductor fabrication", J. Mater. Res., vol.19, pp.2117-2123, 2004. 